\title{
PEMBELAJARAN BERBASIS DIGITAL: STUDI PENGGUNAAN GEOGEBRA BERBANTUAN E-LEARNING UNTUK MENINGKATKAN HASIL BELAJAR MATEMATIKA
}

\author{
Eyus Sudihartinih ${ }^{1}$ \& Wahyudin ${ }^{2}$ \\ 1,2 Departemen Pendidikan Matematika Universitas Pendidikan Indonesia, Bandung, Indonesia \\ 1eyuss84@upi.edu, ${ }^{2}$ wahyudin.mat@upi.edu
}

\begin{abstract}
Abstrak
Penelitian ini menggambarkan pembelajaran berbasis digital, yaitu penggunaan Geogebra berbantuan e-learning, untuk meningkatkan hasil belajar mahasiswa pada konsep bidang dan garis dalam ruang. Penelitian ini adalah pre-experimental dengan jenis one-shot case study dengan partisipan mahasiswa calon dosen matematika pada semester II yang terdiri dari 14 orang laki-laki dan 30 orang perempuan dari salah satu universitas di Indonesia. Hasil penelitian menunjukkan penggunaan Geogebra berbantuan e-learning efektif untuk meningkatkan hasil belajar mahasiswa pada konsep bidang dan garis dalam ruang. Hal ini terlihat dari sebagian besar mahasiswa memperoleh hasil belajar yang maksimal, dan hanya sebagian kecil mahasiswa yang hasil belajarnya masih minimal. Penelitian ini merekomendasikan penggunaan Geogebra dan $e$ learning pada pembelajaran konsep geometri lainnya.
\end{abstract}

Kata kunci: Geogebra, e-learning, model Rasch, geometri, hasil belajar.

\begin{abstract}
This study describes digital-based learning, namely the use of Geogebra assisted by e-learning, to improve student learning outcomes in the concepts of fields and lines in space. This study was pre-experimental with a type of one-shot case study with participants of mathematics teacher candidates in the second semester consisting of 14 men and 30 women from one university in Indonesia. The results showed that the use of Geogebra assisted by e-learning was effective in improving student learning outcomes in the concepts of fields and lines in space. This can be seen from the majority of students obtaining maximum learning outcomes, and only a small percentage of students whose learning outcomes are still minimal. This study recommends the use of Geogebra and $e$ learning in learning other geometry concepts.
\end{abstract}

Keywords: Geogebra, e-learning, Rasch models, geometry, learning outcomes. 
Sudihartinih, E., \& Wahyudin, W. (2019). PEMBELAJARAN BERBASIS DIGITAL: STUDI PENGGUNAAN GEOGEBRA BERBANTUAN E-LEARNING UNTUK MENINGKATKAN HASIL BELAJAR MATEMATIKA. Jurnal Tatsaif, 17(1), 87-103. https://doi.org/10.20414/ita.v17i1.944

\section{PENDAHULUAN}

Berdasarkan trend pembelajaran 4.0 disebutkan bahwa pembelajaran hendaknya merujuk pada pembelajaran berupa praktek dan pembelajaran yang dapat dilaksanakan dimana saja dan kapan saja (SEMOLEC, 2019). Oleh karena itu diperlukan teknologi yang memungkinkan siswa untuk melakukan praktik belajar di mana saja dan kapan saja.

Dalam hal ini, software dan e-learning dapat berperan untuk maksud tersebut. Geogebra adalah salah satu software yang membantu siswa memperoleh perasaan intuitif dan memvisualisasikan proses matematika (Dikovic, 2009). Sejumlah penelitian menunjukkan bahwa penggunakan Geogebra dalam pembelajaran dapat meningkatkan perhatian siswa terhadap matematika (Reis \& Ozdemir, 2009). Sudihartinih dan Purniati (2019) dalam penelitiannya melaporkan bahwa pemahaman mahasiswa dengan pembelajaran menggunakan Geogebra lebih baik daripada menggunakan alat peraga. Sedangkan, E-learning adalah metode pembelajaran yang memungkinkan tersampaikannya bahan ajar kepada peserta didik dengan menggunakan media internet (on line) atau media jaringan komputer lain (Hartley dalam Wahono (2008)). Selain itu menurut Glosary dalam Wahono (2008) e-learning merupakan sistem pendidikan yang menggunakan aplikasi elektronik untuk mendukung mahasiswa belajar kapan saja dan di mana saja agar diperoleh hasil belajar yang baik. Sehingga e-learning adalah srategi untuk memberikan pengetahuan di era digital (Rosenberg \& Foshay, 2007).

Penelitian ini dilatarbelangi oleh dua tantangan dalam pembelajaran matematika, yaitu tantangan teoritis dan tantangan praktis. Secara teoritis, meskipun pembelajaran berbasis digital atau online memiliki sejumlah keuntungan (Davies, and Graff, 2005), penelitian oleh Putrawangsa \& Hasanah (2018) menegaskan bahwa penggunaan media pembelajaran berbasis digital atau online dapat memberikan efek negatif bagi siswa jika tidak digunakan secara tepat guna dan tidak memperhatikan prinisp 
Sudihartinih, E., \& Wahyudin, W. (2019). PEMBELAJARAN BERBASIS DIGITAL: STUDI PENGGUNAAN GEOGEBRA BERBANTUAN E-LEARNING UNTUK MENINGKATKAN HASIL BELAJAR MATEMATIKA. Jurnal Tatsaif, 17(1), 87-103. https://doi.org/10.20414/ita.v17i1.944

integrasi terknologi digital dalam pembelajaran. Adapun prinsip dasar dalam integrasi teknologi digital dalam pembelajaran, khususnya dalam pembelajaran matematika, adalah penggunaan teknologi bertujuan untuk meningkatkan pemahaman konseptual siswa dan mengembangkan kemampuan intuisi siswa dalam bermatematika (Putrawangsa \& Hasanah, 2018). Ini artinya bahwa jangan sampai penggunaan teknologi digital mengakibaktan kemampuan intuisi siswa tidak tereksplorasi atau mengakibatkan siswa tidak memahami objek yang dikaji secara konseptual. Dalam hal ini, diharapakan teknologi digital dapat berperan sebagai 'means to develop conceptual understanding', yaitu teknologi digital yang berfungsi sebagai lingkungan belajar untuk mengembangkan pemahaman konseptual siswa tentang konsep matematika (Putrawangsa \& Hasanah, 2018). Bagaimana mengintegrasikan teknologi digital dalam pembelajaran matemaitka sehingga dapat berperan sebagai 'means to develop conceptual understanding', hingga saat ini, masih menjadi tantangan peneliti dan pendidik matematika.

Sedangkan secara praktis, diketahui bahwa tujuan mempelajari geometri adalah agar siswa mempunyai rasa percaya diri dalam kemampuan bermatematika, menjadi problem solver yang baik, dapat berkomunikasi, dan bernalar secara matematis (Abdussakir, 2002). Namun kenyataannya mahasiswa calon guru matematika masih memiliki kemampuan yang rendah dalam materi geometri. Terbukti dengan hasil tes level berpikir geometri yang pada umumnya masih rendah (Sudihartinih dan Mulyana, 2014). Hasil penelitian lainnya juga menunjukkan bahwa mahasiswa masih kesulitan dalam belajar geometri (Gal \& Linchevski, 2010; Purniati dan Sudihartini, 2015; Sudihartinih, 2018a; Sudihartinih, 2018b). Sehingga diperlukan pembalajaran yang dapat memudahkan mahasiswa belajar geometri.

Berdasarkan kedua tantangan tersebut, penelitian ini mengkaji tentang bagaiamana integrasi teknologi digital, yaitu software Geogebra berbatuan $e$ learning, dalam pembelajaran geometri analitik untuk meningkatkan hasil 
Sudihartinih, E., \& Wahyudin, W. (2019). PEMBELAJARAN BERBASIS DIGITAL: STUDI PENGGUNAAN GEOGEBRA BERBANTUAN E-LEARNING UNTUK MENINGKATKAN HASIL BELAJAR MATEMATIKA. Jurnal Tatsaif, 17(1), 87-103. https://doi.org/10.20414/ita.v17i1.944

belajar siswa. Lebih spesifik, rumusan masalah dalam penelitian ini adalah bagaimana penggunaan Geogebra berbantuan e-learning untuk meningkatkan hasil belajar mahasiswa pada konsep bidang dan garis dalam ruang.

\section{LANDASAN TEORI}

\section{Hasil Belajar}

Berikut katerangan tentang hasil belajar. Pertama, menurut Sudjana (1991) bahwa hasil belajar adalah kemampuan-kemampuan yang dimiliki siswa setelah ia menerima pengalaman belajarnya. Kedua, Centre for Teaching Support \& Innovation - University of Toronto bahwa hasil belajar adalah pernyataan yang menggambarkan pengetahuan atau keterampilan yang harus diperoleh siswa pada akhir tugas, kelas, kursus, atau program tertentu, dan membantu siswa memahami mengapa pengetahuan dan keterampilan itu akan berguna bagi mereka. Ketiga, menurut Nasution bahwa hasil belajar adalah suatu perubahan yang terjadi pada individu yang belajar, bukan saja perubahan mengenai pengetahuan, tetapi juga untuk membentuk kecakapan dan penghargaan dalam diri pribadi yang belajar (Lestari, 2015).

Pada penelitian ini, definisi hasil belajar adalah gambaran pengetahuan mahasiswa yang diperoleh setelah mengikuti perkuliahan, dan diukur menggunakan instrumen tes pada saat ujian akhir semester.

\section{Geogebra}

Geogebra adalah software yang menggabung geometri, aljabar, dan kalkulus ke dalam satu paket yang mudah digunakan untuk belajar dan mengajar matematika dari tingkat dasar hingga universitas, tersedia gratis di Internet, dan telah diterjemahkan ke 36 bahasa (Hohenwarter, et all, 2008). Geogebra menyediakan banyak kemungkinan untuk membantu siswa memperoleh perasaan intuitif dan memvisualisasikan proses matematika secara memadai (Dikovic, 2009). Geogebra dapat 
Sudihartinih, E., \& Wahyudin, W. (2019). PEMBELAJARAN BERBASIS DIGITAL: STUDI PENGGUNAAN GEOGEBRA BERBANTUAN E-LEARNING UNTUK MENINGKATKAN HASIL BELAJAR MATEMATIKA. Jurnal Tatsaif, 17(1), 87-103. https://doi.org/10.20414/ita.v17i1.944

bermanfaat dalam hal visibilitas dan pemikiran konseptual siswa (Akkaya, Tatar, dan Kagizmanli, 2011).

Geogebra pada penelitian ini adalah software matematika yang digunakan mahasiswa untuk membantu menyelesaikan masalah geometri dan visualisasi geometri.

\section{E-learning}

Pembelajaran E-learning menurut Hartley adalah suatu jenis belajar mengajar yang memungkinkan tersampaikannya bahan ajar kepada peserta didik dengan menggunakan media internet atau media jaringan komputer lain (Wahono, 2008). Menurut Glosary, e-learning merupakan sistem pendidikan yang menggunakan aplikasi elektronik untuk mendukung belajar mengajar dengan media internet, jaringan komputer, maupun komputer standalone (Wahono, 2008). Dengan demikian melalui e-learning, pembelajaran dapat dilaksanakan dimana dan kapan saja, pembelajaran dapat dilaksanakan secara personal, dan siswa memiliki kesempatan dalam menentukan materi yang akan dipelajari.

E-learning dalam penelitian ini adalah media internet yang dapat membantu mahasiswa dalam belajar dan mengumpulkan tugas geometri.

\section{METODE}

Penelitian ini mengikuti penelitian dari Sudihartinih dan Wahyudin (2019). Penelitian ini adalah pre-experimental dengan jenis one-shot case study yang melibatkan satu kelas mahasiswa calon dosen matematika pada semester kedua yang terdiri dari 14 orang laki-laki dan 30 orang perempuan di salah satu universitas di Indonesia. Mahasiswa tersebut mendapatkan pembelajaran dengan Geogebra berbantuan e-learning dalam konsep bidang dan garis dalam ruang. Setiap mahasiswa membawa laptop yang telah diinstal software Geogebra. Selanjutnya mahasiswa dapat menyelesaikan masalah geometri dengan menggunakan software tersebut.

Berikut contoh visualisasi dari persamaan bidang $3 x+2 y-5 z=10$ dengan 
Sudihartinih, E., \& Wahyudin, W. (2019). PEMBELAJARAN BERBASIS DIGITAL: STUDI PENGGUNAAN GEOGEBRA BERBANTUAN E-LEARNING UNTUK MENINGKATKAN HASIL BELAJAR MATEMATIKA. Jurnal Tatsaif, 17(1), 87-103. https://doi.org/10.20414/ita.v17i1.944

menggunakan Geogebra.

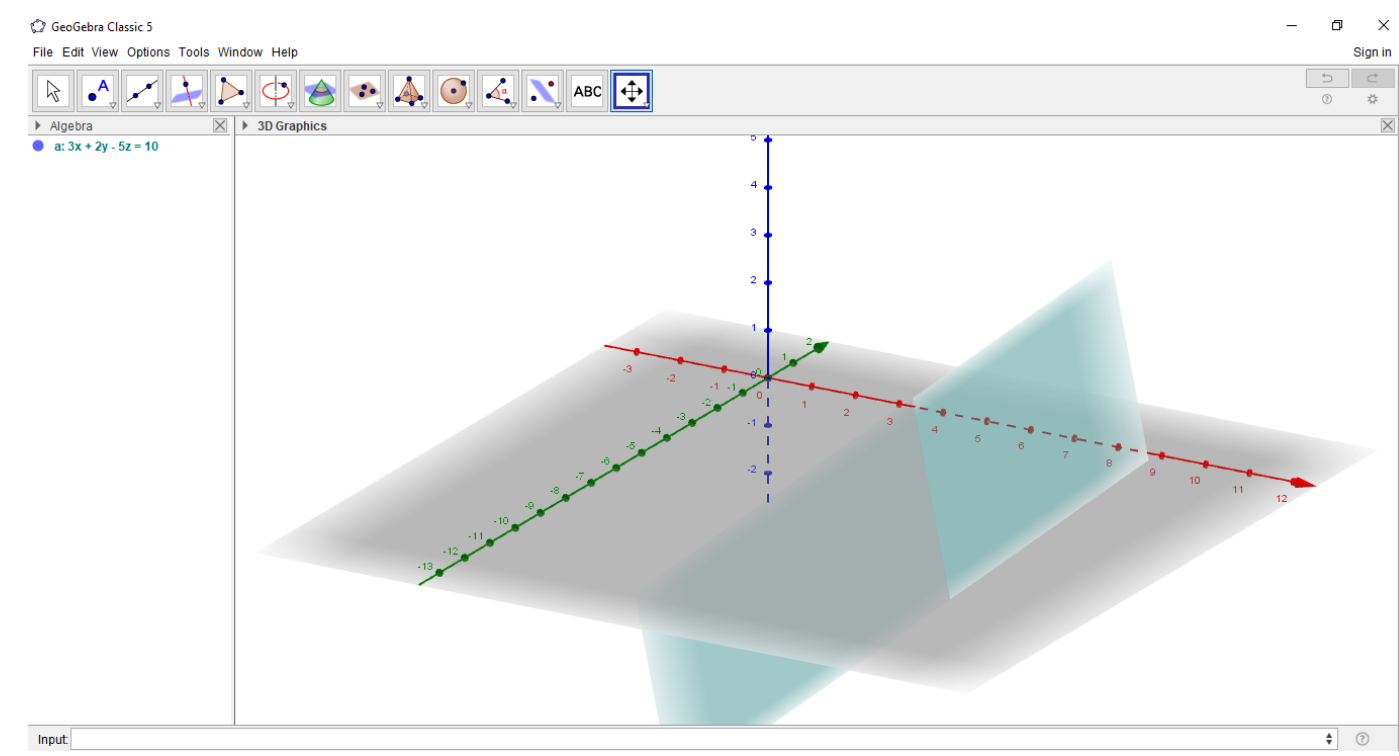

Gambar 1. Contoh persamaan bidang dalam Geogebra

E-learning yang digunakan mahasiswa telah disediakan oleh universitas yang bisa dilihat di http://spot.upi.edu/ dan oleh departemen bisa diakses di https://elmath.matematika.upi.edu/. Kedua e-learning tersebut memiliki kelebihannya masing-masing sehingga peneliti menggunakan keduanya. Melaui web tersebut peneliti dapat menguploud tugas-tugas, bahan ajar, dan slot untuk pengumpulan tugas mahasiswa setelah perkuliahan.

Instrumen dalam penelitian ini adalah tes uraian pada konsep bidang dan garis dalam ruang yang didesain oleh dosen pengampu yaitu peneliti. Tes diberikan pada mahasiswa dan diisi pada kertas yang diberikan pada saat ujian akhir semester. Selanjutnya hasil tes dinilai oleh dosen pengampu yaitu dosen pengampu menggunakan rubrik penilaian.

Adapun langkah-langkah penelitian yaitu sebagai berikut:

1. Studi literature.

2. Desain bahan ajar dengan Geogebra.

3. Desain konten e-learning.

4. Desain instrumen tes.

5. Pelaksanaan pembelajaran dengan Geogebra berbatuan e-learning. Sehingga pada saat pembelajaran mahasiswa belajar menggunakan 
Sudihartinih, E., \& Wahyudin, W. (2019). PEMBELAJARAN BERBASIS DIGITAL: STUDI PENGGUNAAN GEOGEBRA BERBANTUAN E-LEARNING UNTUK MENINGKATKAN HASIL BELAJAR MATEMATIKA. Jurnal Tatsaif, 17(1), 87-103. https://doi.org/10.20414/ita.v17i1.944

Geogebra dan e-learning digunakan untuk melampirkan tugas, materi dan pengumpulan tugas setelah pembelajaran.

6. Tes selama 30 menit dilakukan pada saat UAS yaitu pertemuan ke 16 .

7. Analisis data menggunakan model Rasch dengan software Ministep yang gratis unduh di internet.

8. Laporan dan diseminasi.

Analisis data hasil belajar mahasiswa dalam penelitian ini menggunakan model Rasch. Model Rasch adalah Item-Response Theory (IRT) yang memberikan pengukuran alternatif yang dapat menilai kualitas instrumen yang andal dan valid. Kelebihan model Rasch adalah dapat menyediakan skala linier dalam interval yang sama, memprediksi data hilang, memberikan perkiraan yang lebih tepat, mendeteksi ketidakakuratan model serta menghasilkan pengukuran yang dapat ditiru (Sumintono dan Widhiarso, 2014). Validitas item diukur dari Standardized Residual Correlation, Point Measure Correlation (PTMea Corr.), INFIT dan OUTFIT mean square (MNSQ) (Razali dan Shahbodin, 2016). OUTFIT mean square (MNSQ) harus dalam interval antara 0,60 dan 1,40 dan nilai INFIT and OUTFIT ZSTD harus dalam interval antara -2 hingga +2 (Sumintono, and Widhiarso, 2014). Jika nilai dalam PTMea Corr. positif (+) maka item mengukur konstruk, dan sebaliknya. Sehingga jika PTMea Corr. negatif (-) maka item harus dibuang atau disempurnakan karena terlalu sulit / mudah atau tidak mengarah pada pertanyaan (tidak fokus) (Bond dan Fox, 2007).

\section{HASIL DAN PEMBAHASAN}

Pada bagian ini dibahas mengenai eksperimen pembelajaran yang dilakukan, analisis data hasil belajar, dan implikasi teoritis dari hasil penelitian ini.

\section{Pembelajaran dengan Geogebra Berbantuan E-learning}

Berikut contoh rancangan pembelajaran dengan Geogebra berbantuan e-learning. 
Sudihartinih, E., \& Wahyudin, W. (2019). PEMBELAJARAN BERBASIS DIGITAL: STUDI PENGGUNAAN GEOGEBRA BERBANTUAN E-LEARNING UNTUK MENINGKATKAN HASIL BELAJAR MATEMATIKA. Jurnal Tatsaif, 17(1), 87-103. https://doi.org/10.20414/ita.v17i1.944

Tabel 1. Rancangan Pembelajaran

\begin{tabular}{|c|c|}
\hline Kegiatan & Deskripsi Kegiatan \\
\hline Pen & $\begin{array}{l}\text { 1. Memimpin doa (Meminta seorang mahasiswa untuk memimpin } \\
\text { doa) } \\
\text { 2. Mengecek kehadiran mahasiswa dan meminta mahasiswa untuk } \\
\text { menyiapkan perlengkapan dan peralatan yang diperlukan, } \\
\text { diantaranya laptop. } \\
\text { 3. Dosen memberikan gambaran tentang pentingnya belajar } \\
\text { geometri diantaranya untuk menjadi problem solver yang baik. } \\
\text { 4. Dosen menyampaikan tujuan pembelajaran yang ingin dicapai, } \\
\text { yaitu dapat menyelesaikan masalah pada konsep bidang dan } \\
\text { garis dalam ruang. }\end{array}$ \\
\hline Inti & $\begin{array}{l}\text { Fase 1: Orientasi mahasiswa pada masalah } \\
\text { Dosen mengajukan masalah bidang dan garis dalam ruang di } \\
\text { sekitar kelas. } \\
\text { Fase 2: Mengorganisasikan siswa belajar } \\
\text { 1. Dosen meminta mahasiswa membentuk kelompok heterogen } \\
\text { (dari sisi kemampuan dan gender). } \\
\text { 2. Dosen meminta mahasiswa menyelesaikan masalah yang telah } \\
\text { diberikan dengan Geogebra. } \\
\text { 3. Dosen berkeliling dan memberi bantuan (scaffolding) berkaitan } \\
\text { kesulitan yang dialami mahasiswa secara individu, kelompok, } \\
\text { atau klasikal. } \\
\text { Fase 3: Membimbing penyelidikan individu dan kelompok. } \\
\text { Meminta mahasiswa menurunkan persamaan bidang dalam ruang } \\
\text { adalah ax+by+cz=k. Dan dosen memberi bantuan (scaffolding) } \\
\text { berkaitan kesulitan yang dialami mahasiswa secara individu, } \\
\text { kelompok, atau klasikal. } \\
\text { Fase 4: Mengembangkan dan menyajikan hasil karya } \\
\text { 1. Dosen meminta beberapa mahasiswa presentasi hasil diskusi. } \\
\text { 2. Dosen memberikan beberapa soal tentang bidang dan garis } \\
\text { dalam ruang. Dan meminta mahasiswa menyelesaikannya } \\
\text { dengan bantuan Geogebra. } \\
\text { Fase 5: Menganalisa dan mengevaluasi proses pemecahan } \\
\text { masalah. } \\
\text { 1. Dosen meminta beberapa mahasiswa mempresentasikan hasil } \\
\text { penyelesaian soal. } \\
\text { 2. Dosen memberi kesempatan kepada mahasiswa lain } \\
\text { mengomentari penyelesaian soal. } \\
\text { 3. Dosen melibatkan mahasiswa mengevaluasi penyelesaian soal } \\
\text { tersebut. Dan memberi kesempatan kepada kelompok lain yang } \\
\text { mempunyai jawaban berbeda. }\end{array}$ \\
\hline $\mathrm{P}$ & $\begin{array}{l}\text { 1. Siswa diminta menyimpulkan materi. } \\
\text { 2. Dosen meminta mahasiswa menyelesaikan soal dalam e- } \\
\text { learning, dan mengumpulkannya di e-learning. } \\
\text { 3. Dosen juga mengupoud bahan ajar dalam e-learning, sehingga } \\
\text { mahasiswa yang membutuhkan dapat mengunduhnya. } \\
\text { 4. Dosen mengakhiri kegiatan belajar. }\end{array}$ \\
\hline
\end{tabular}


Sudihartinih, E., \& Wahyudin, W. (2019). PEMBELAJARAN BERBASIS DIGITAL: STUDI PENGGUNAAN GEOGEBRA BERBANTUAN E-LEARNING UNTUK MENINGKATKAN HASIL BELAJAR MATEMATIKA. Jurnal Tatsaif, 17(1), 87-103. https://doi.org/10.20414/ita.v17i1.944

Berikut contoh desain bahan ajar yaitu diantaranya adalah mahasiswa diminta menyelesaikan masalah tentang persamaan bidang yang melalui titik $(-1,-2,-3)$ dan tegak lurus vektor $[1,4,2]$. Maka salah satu solusinya adalah mahasiswa dapat menentukan titik $(-1,-2,-3)$ dan vektor $[1,4,2]$ pada Geogebra. Selanjutnya buat garis sejajar vector tersebut dan buat bidang yang sejajar garis, maka bidang tersebut melalui titik $(-1,-2,-3)$ dan tegak lurus vektor $[1,4,2]$ dengan persamaan $0,22 x 0,87 y+0,44 z=-3,27$.

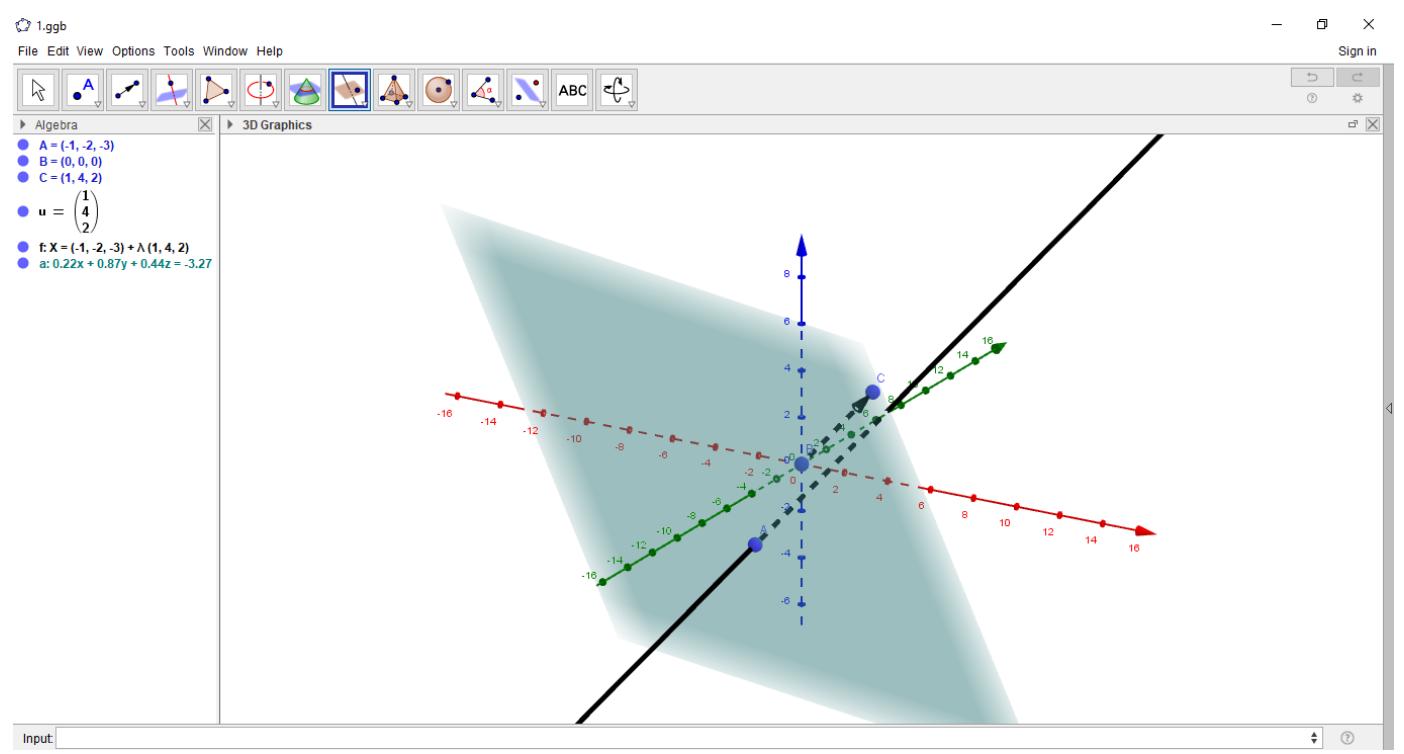

Gambar 2. Solusi soal dengan Geogebra

Setelah perkuliahan selesai, dosen menguploud bahan ajar dan tugas dalam e-learning. Mahasiswa diharuskan mengumpulkan tugas individu dalam e-learning dengan batas waktu tertentu dan yang terlambat tidak dapat menguploudnya. Adapun konten e-learning adalah beberapa bahan ajar dan tugas. Berikut contoh kontennya. 
Sudihartinih, E., \& Wahyudin, W. (2019). PEMBELAJARAN BERBASIS DIGITAL: STUDI PENGGUNAAN GEOGEBRA BERBANTUAN E-LEARNING UNTUK MENINGKATKAN HASIL BELAJAR MATEMATIKA. Jurnal Tatsaif, 17(1), 87-103. https://doi.org/10.20414/ita.v17i1.944

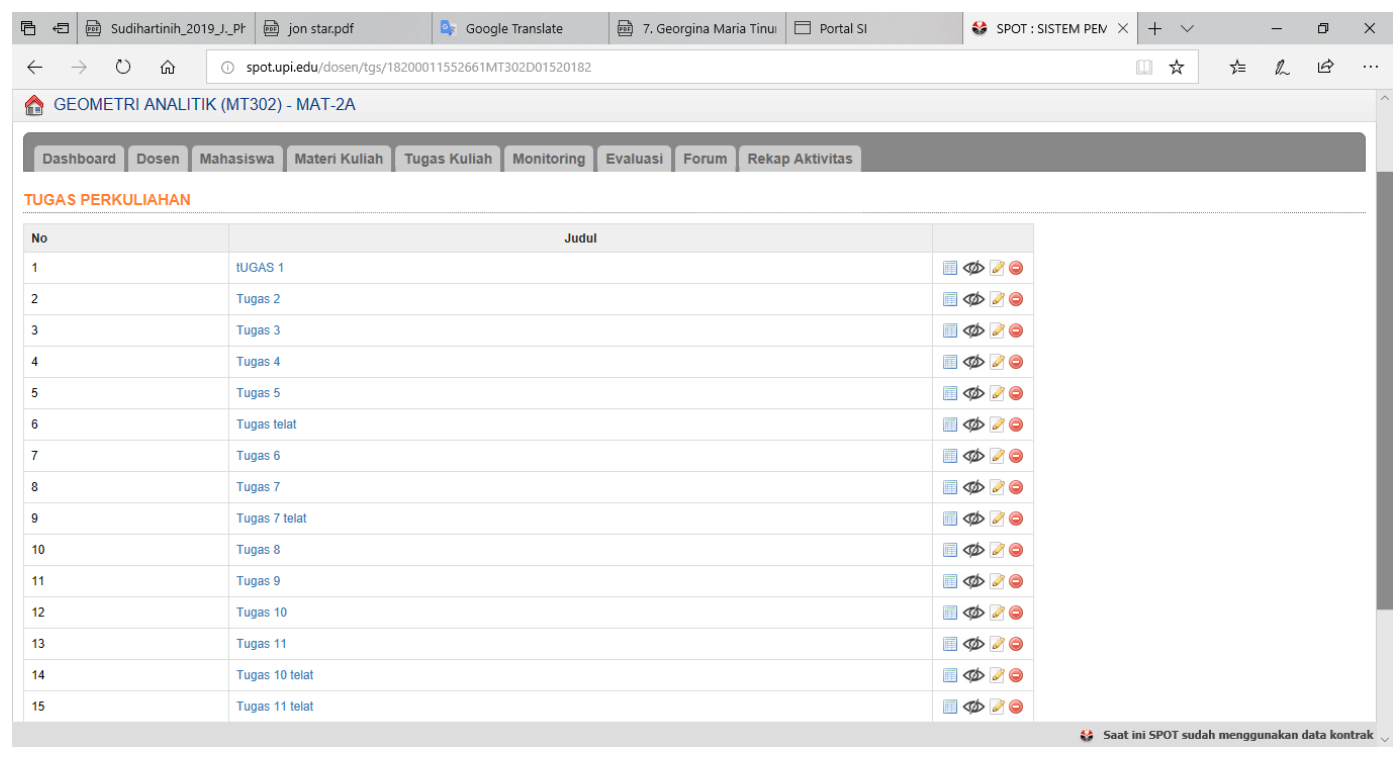

Gambar 3. Contoh konten e-learning

\section{Instrumen Pengukuran Hasil Belajar Mahasiswa}

Berikut bentuk soal-soal yang diberikan pada mahasiswa untuk mengukur hasil belajar mahasiswa.

a. Carilah persamaan bidang yang melalui titik $(1,2,3)$ dan tegak lurus vektor $[-1,4,2]$.

b. Carilah persamaan garis yang melalui $(3,4,1)$ dan tegak lurus bidang $3 \mathrm{x}+\mathrm{y}-\mathrm{z}-6=0$.

Berdasarkan Tabel 1 hasil analisis data tes dengan model Rasch diketahui mean measure $+0,00$ artinya rata-rata item soal adalah sedang. Nilai Item reability adalah 0,94 yang berarti soal bagus sekali (Sumintono, B.; and Widhiarso, W., 2014). Sehingga kualitas soal bagus sekali.

Tabel 1. Ringkasan Pengukuran Item Soal dengan Model Rasch

\begin{tabular}{ccccccccc}
\hline & Total & & & Model & \multicolumn{2}{c}{ Infit } & \multicolumn{2}{c}{ Outfit } \\
\cline { 6 - 9 } & score & Count & Measure & error & MNSQ & ZSTD & MNSQ & ZSTD \\
\hline \multirow{2}{*}{ MEAN } & & & & & & & & \\
\end{tabular}

Berdasarkan Tabel 2 berikut INFIT dan OUTFIT MNSQ pada soal nomor 2 adalah 0,88 dan 1,2, sedangkan soal nomor 2 0,54 dan 2,48, artinya soal nomor 2 
Sudihartinih, E., \& Wahyudin, W. (2019). PEMBELAJARAN BERBASIS DIGITAL: STUDI PENGGUNAAN GEOGEBRA BERBANTUAN E-LEARNING UNTUK MENINGKATKAN HASIL BELAJAR MATEMATIKA. Jurnal Tatsaif, 17(1), 87-103. https://doi.org/10.20414/ita.v17i1.944

baik untuk pengukuran, sedangkan soal nomor 1 kurang baik dalam pengukuran (Sumintono and Widhiarso, 2014). INFIT dan OUTFIT ZSTD pada soal nomor 2 adalah -0,12 dan 0,55, sedangkan pada soal nomor 1 adalah -1,14 dan 1,50 artinya data memiliki perkiraan logis (Sumintono and Widhiarso, 2014). Jika nilai dalam PTMea Corr. Semua soal adalah positif maka item mengukur konstruk, sehingga semua item soal digunakan (Bond and Fox, 2007). Item s2 dengan logit $+1,28$ menunjukkan item soal paling sulit, sedangkan item s1 dengan -1,28 logit menunjukkan item soal yang paling mudah (Sumintono, B.; and Widhiarso, W., 2014).

Tabel 2. Statistik item soal dari model Rasch

\begin{tabular}{ccccccccc}
\hline \multirow{2}{*}{ Measure } & \multicolumn{1}{c}{ Model } & \multicolumn{2}{c}{ Infit } & \multicolumn{2}{c}{ Outfit } & \multicolumn{2}{c}{ Pt-measure } & \multirow{2}{*}{ Item } \\
\cline { 2 - 8 } 1,28 & S.E. & MNSQ & ZSTD & MNSQ & ZSTD & Correlate & Exponential & \\
\hline \multirow{2}{*}{0,36} & 0,88 & $-0,12$ & 1,20 & 0,55 & 0,92 & 0,93 & S1 \\
$-1,28$ & 0,28 & 0,54 & $-1,14$ & 2,48 & 1,50 & 0,76 & 0,75 & S2 \\
\hline
\end{tabular}

\section{Hasil Belajar Mahasiswa}

Berikut data (Tabel 3) deskriptif hasil tes mahasiswa. Berdasarkan table, diketahui bahwa skor tertinggi pada kedua soal adalah lima dan skor terendahnya adalah satu. Rata-rata skor nomor 1 dan nomor 2 secara berturut-turut adalah 4,59 dan 3,84.

Tabel 3. Skor mahasiswa dalam setiap soal

\begin{tabular}{lrr}
\hline Partisipan & Soal 1 & Soal 2 \\
\hline 01P & 3 & 3 \\
02P & 5 & 4 \\
03L & 5 & 1 \\
$04 \mathrm{~L}$ & 5 & 5 \\
$05 \mathrm{P}$ & 5 & 5 \\
$06 \mathrm{P}$ & 5 & 5 \\
$07 \mathrm{P}$ & 5 & 5 \\
$08 \mathrm{P}$ & 5 & 1 \\
$09 \mathrm{P}$ & 5 & 5 \\
10P & 5 & 5 \\
11L & 5 & 2 \\
12P & 5 & 5 \\
13L & 5 & 5
\end{tabular}


Sudihartinih, E., \& Wahyudin, W. (2019). PEMBELAJARAN BERBASIS DIGITAL: STUDI PENGGUNAAN GEOGEBRA BERBANTUAN E-LEARNING UNTUK MENINGKATKAN HASIL BELAJAR MATEMATIKA. Jurnal Tatsaif. 17(1), 87-103. https://doi.org/10.20414/ita.v17i1.944

\begin{tabular}{|c|c|c|}
\hline $14 \mathrm{P}$ & 5 & 5 \\
\hline $15 \mathrm{P}$ & 5 & 1 \\
\hline $16 \mathrm{~L}$ & 5 & 5 \\
\hline $17 \mathrm{~L}$ & 5 & 5 \\
\hline $18 \mathrm{~L}$ & 5 & 5 \\
\hline 19L & 5 & 5 \\
\hline $20 \mathrm{P}$ & 2 & 2 \\
\hline $21 \mathrm{P}$ & 3 & 2 \\
\hline $22 \mathrm{P}$ & 5 & 5 \\
\hline $23 \mathrm{P}$ & 4 & 5 \\
\hline $24 \mathrm{P}$ & 5 & 5 \\
\hline $25 \mathrm{P}$ & 5 & 5 \\
\hline $26 \mathrm{P}$ & 5 & 5 \\
\hline $27 \mathrm{P}$ & 5 & 1 \\
\hline $28 \mathrm{~L}$ & 5 & 5 \\
\hline $29 \mathrm{~L}$ & 5 & 5 \\
\hline $30 \mathrm{~L}$ & 5 & 5 \\
\hline $31 \mathrm{P}$ & 5 & 5 \\
\hline $32 \mathrm{~L}$ & 5 & 5 \\
\hline $33 \mathrm{P}$ & 2 & 1 \\
\hline $34 \mathrm{~L}$ & 5 & 5 \\
\hline $35 \mathrm{P}$ & 5 & 1 \\
\hline $36 \mathrm{~L}$ & 5 & 1 \\
\hline $37 \mathrm{P}$ & 5 & 1 \\
\hline $38 \mathrm{P}$ & 1 & 1 \\
\hline $39 \mathrm{P}$ & 5 & 5 \\
\hline $40 \mathrm{P}$ & 5 & 5 \\
\hline $41 \mathrm{P}$ & 5 & 5 \\
\hline $42 \mathrm{P}$ & 2 & 2 \\
\hline $43 \mathrm{P}$ & 5 & 5 \\
\hline $44 \mathrm{P}$ & 5 & 5 \\
\hline Rata-rata & 4,590909 & 3,840909 \\
\hline
\end{tabular}

Berdasarkan Tabel 4 tentang Guttmanscalogram berikut diketahui bahwa 28 orang mahasiswa memperoleh skor maksimum dan satu orang memiliki skor minimum, serta hanya dua orang yang tidak dapat menjawab kedua soal. Artinya sebagian besar siswa mendapat skor maksimum, dan hanya sebagian kecil siswa mendapat skor minimum (Suherman, 2003). 
Sudihartinih, E., \& Wahyudin, W. (2019). PEMBELAJARAN BERBASIS DIGITAL: STUDI PENGGUNAAN GEOGEBRA BERBANTUAN E-LEARNING UNTUK MENINGKATKAN HASIL BELAJAR MATEMATIKA. Jurnal Tatsaif, 17(1), 87-103. https://doi.org/10.20414/ita.v17i1.944

Tabel 4. Guttmanscalogram

\begin{tabular}{|c|c|c|}
\hline $\begin{array}{l}\text { Number of } \\
\text { respondents }\end{array}$ & $\frac{\text { Item }}{12}$ & \\
\hline 4 & 55 & 04L \\
\hline 5 & 55 & $05 \mathrm{P}$ \\
\hline 6 & 55 & $06 \mathrm{P}$ \\
\hline 7 & 55 & $07 \mathrm{P}$ \\
\hline 9 & 55 & $09 \mathrm{P}$ \\
\hline 10 & 55 & $10 \mathrm{P}$ \\
\hline 12 & 55 & $12 \mathrm{P}$ \\
\hline 13 & 55 & $13 \mathrm{~L}$ \\
\hline 14 & 55 & $14 \mathrm{P}$ \\
\hline 16 & 55 & $16 \mathrm{~L}$ \\
\hline 17 & 55 & $17 \mathrm{~L}$ \\
\hline 18 & 55 & $18 \mathrm{~L}$ \\
\hline 19 & 55 & $19 \mathrm{~L}$ \\
\hline 22 & 55 & $22 \mathrm{P}$ \\
\hline 24 & 55 & $24 \mathrm{P}$ \\
\hline 25 & 55 & $25 \mathrm{P}$ \\
\hline 26 & 55 & $26 \mathrm{P}$ \\
\hline 28 & 55 & $28 \mathrm{~L}$ \\
\hline 29 & 55 & $29 \mathrm{~L}$ \\
\hline 30 & 55 & $30 \mathrm{~L}$ \\
\hline 31 & 55 & $31 P$ \\
\hline 32 & 55 & $32 \mathrm{~L}$ \\
\hline 34 & 55 & $34 \mathrm{~L}$ \\
\hline 39 & 55 & $39 P$ \\
\hline 40 & 55 & $40 P$ \\
\hline 41 & 55 & $41 P$ \\
\hline 43 & 55 & $43 \mathrm{P}$ \\
\hline 44 & 55 & $44 \mathrm{P}$ \\
\hline 2 & 54 & $02 \mathrm{P}$ \\
\hline 23 & 45 & $23 \mathrm{P}$ \\
\hline 11 & 52 & $11 \mathrm{~L}$ \\
\hline 1 & 33 & $01 P$ \\
\hline 3 & 51 & 03L \\
\hline 8 & 51 & $08 \mathrm{P}$ \\
\hline 15 & 51 & $15 \mathrm{P}$ \\
\hline 27 & 51 & $27 \mathrm{P}$ \\
\hline 35 & 51 & $35 \mathrm{P}$ \\
\hline 36 & 51 & $36 \mathrm{~L}$ \\
\hline 37 & 51 & $37 P$ \\
\hline 21 & 32 & $21 P$ \\
\hline 20 & 22 & $20 \mathrm{P}$ \\
\hline 42 & 22 & $42 \mathrm{P}$ \\
\hline 33 & 21 & $33 \mathrm{P}$ \\
\hline
\end{tabular}


Sudihartinih, E., \& Wahyudin, W. (2019). PEMBELAJARAN BERBASIS DIGITAL: STUDI PENGGUNAAN GEOGEBRA BERBANTUAN E-LEARNING UNTUK MENINGKATKAN HASIL BELAJAR MATEMATIKA. Jurnal Tatsaif, 17(1), 87-103. https://doi.org/10.20414/ita.v17i1.944

\section{Implikasi}

Berdasarkan temuan penelitian, pembelajaran menggunakan Geogebra berbantuan e-learning dapat memfasilitasi mahasiswa untuk belajar konsep bidang dan garis dalam ruang. Kesimpulan ini didasarkan pada argumentasi bahwa Geogebra memeliki sejumlah kelebihan yang dapat membantu siswa dalam belajar.

Pertama, hasil penelitian ini menunjukkan bahwa Geogebra efektif dalam membantu siswa dalam memperoleh perasaan intuitif dan memvisualisasikan proses matematika (Dikovic, 2009). Hal ini sejalan dengan pandangan Putrawangsa \& Hasanah (2018) yang menegaskan bahwa, dalam konteks pembelajaran matematika, media belajar digital yang efektif adalah media belajar yang dapat menstimulus intuisi siswa mengenai konsep matematika yang dipelajarinya. Dalam hal ini, penggunaan teknologi jangan sampai berakibat pada tergantinya penggunaan intuisi siswa dalam bermatematika, tetapi sebaliknya teknologi tersebut berfungsi untuk meningkatkan kemampuan intuisi siswa dalam bermatematika.

Kedua, hasil penelitian ini menunjukkan bahwa Geogebra dapat membantu pengembangan pemikiran konseptual siswa (Akkaya, Tatar, Kagizmanli, 2011). Sejalan dengan ini, Putrawangsa \& Hasanah menegaskan bahwa terdapat tiga fungsi dedaktik dari teknologi digital dalam pembelajaran matematika, yaitu: (1) Technology for doing mathematics, yaitu teknologi yang berfungsi sebagai alternatif alat pengganti media pembelajaran untuk melakukan kegiatan bermatematika; (2) Technology for practicing skills, yaitu teknologi yang berfungsi sebagai lingkungan belajar untuk mengasah keterampilan matematika tertentu; (3) Technology for developing conceptual understanding, yaitu teknologi digital yang berfungsi sebagai media belajar untuk mengembangkan pemahaman konseptual siswa tentang konsep matematika tertentu. Dari ketiga fungsi tersebut, fungsi dedaktik 
Sudihartinih, E., \& Wahyudin, W. (2019). PEMBELAJARAN BERBASIS DIGITAL: STUDI PENGGUNAAN GEOGEBRA BERBANTUAN E-LEARNING UNTUK MENINGKATKAN HASIL BELAJAR MATEMATIKA. Jurnal Tatsaif, 17(1), 87-103. https://doi.org/10.20414/ita.v17i1.944

yang ketiga, yaitu technology for developing conceptual understanding, adalah yang paling diharapkan dari integrasi teknologi digital dalam pembelajaran matematika. Dalam hal ini, penelitian ini berhasil menunjukkan bagaimana pembelajaran yang mengintegrasikan software Geogebra dan e-learning sebagai media belajar untuk mengembangkan pemahaman konseptual siswa tentang konsep matematika pada kajian tentang bidang dan garis dalam ruang.

Berdasarkan hasil penelitian ini, kelebihan lainnya dari Geogebra adalah efektif membantu siswa mengenali objek matematika dengan mudah (Choi, 2010) sehingga proses belajar mengajar menjadi lebih efektif (Tran, et all, 2014).

Efektivitas Geogebra tersebut juga didukung dengan keberadaan $e$ learning yang memberikan manfaat bagi mahasiswa untuk dapat belajar kapan saja dan di mana saja (Glosary dalam Wahono, 2008). Dengan demikian, hasil penelitian ini menunjukkan bahwa penggunaan $e$ learning adalah srategi belajar yang relevan untuk pembelajaran di era dimana dunia sudah bertransformasi ke dunia digital (Rosenberg \& Foshay, 2007).

\section{KESIMPULAN}

Penggunaan Geogebra berbantuan e-learning untuk meningkatkan hasil belajar mahasiswa pada konsep bidang dan garis dalam ruang telah berhasil. Terlihat dari sebagian besar mahasiswa mendapat hasil belajar yang maksimal dalam konsep bidang dan garis dalam ruang. Sehingga penggunaan Geogebra dan e-learning dapat diujicobakan pada konsep geometri lainnya.

\section{PENGAKUAN}

Penulis mengucapkan terima kasih pada mahasiswa departemen pendidikan matematika pada salah satu universitas di Indonesia yang telah membantu selesainya penelitian ini. 
Sudihartinih, E., \& Wahyudin, W. (2019). PEMBELAJARAN BERBASIS DIGITAL: STUDI PENGGUNAAN GEOGEBRA BERBANTUAN E-LEARNING UNTUK MENINGKATKAN HASIL BELAJAR MATEMATIKA. Jurnal Tatsaif. 17(1), 87-103. https://doi.org/10.20414/ita.v17i1.944

\section{DAFTAR PUSTAKA}

Abdussakir. (2002). Pembelajaran Geometri Berdasarkan Teori Van Hiele Berbantuan Komputer. Prosiding Konferensi Nasional Matematika. Malang: Universitas Negeri Malang.

Akkaya A, Tatar E, Kagizmanli, T B . (2011). Using Dynamic Software in Teaching of the Symmetry in Analytic Geometry: The Case of Geogebra . Procedia Social and Behavioral Sciences, 15 2540-2544.

Bond, T. G. and Fox, C. M. (2007). Applying The Rasch Model: Fundamental Measurement in the Human Sciences. Mahwah, N.J.: Lawrence Erlbaum Associates Publishers.

Choi, K. S. (2010). Motivating Students in Learning Mathematics with Geogebra. Annals Computer Science, 8(2).

Davies, J., and Graff, M. (2005). Performance in e-learning: online participation and student grades. British Journal of Educational Technology, 36(4), 657-663.

Dikovic, L. (2009). Implementing Dynamic Mathematics Resources with Geogebra at the College Level. iJET 4(3).

Gal, H. \& Linchevski, L. . (2010). To see or not to see: analyzing difficulties in geometry from the perspective of visual perception. Educational Studies in Mathematics, 74(2), 163-183.

Hohenwarter M, Hohenwarter J, Kreis Y, Lavicza Z . (2008). Teaching and calculus with free dynamic mathematics software Geogebra. 11th International Congres Mathematical Educatin. Mexico.

Lestari, I. (2015). Pengaruh Waktu Belajar dan Minat Belajar Terhadap Hasil Belajar Matematika. Jurnal Formatif 3(2), 115-125.

Purniati, T. dan Sudihartinih, E. (2015). Visual Aids in Analytical Geometry Course in Conic Concept. Proocedings International Seminar on Mathematics, Science and Computer Science Education. Bandung: FPMIPA UPI.

Razali, S.N.; and Shahbodin, F. (2016). Questionnaire on perception of online collaborativelearning: measuring validity and reliability using Rasch model. Proceedings of the 4th International Conference on User Science and Engineering. Melaka, Malaysia, 1.

Reis Z A, Ozdemir S . (2009). Using Geogebra as an information technology tool: parabola teaching. Procedia Social and Behavioral Sciences , 9(1), 565-572.

Rosenberg, M. J. \& Foshay, R. (2007). E-learning: Strategies for delivering knowledge in the digital age. Performance Improvement, 41(5), 50-51. 
Sudihartinih, E., \& Wahyudin, W. (2019). PEMBELAJARAN BERBASIS DIGITAL: STUDI PENGGUNAAN GEOGEBRA BERBANTUAN E-LEARNING UNTUK MENINGKATKAN HASIL BELAJAR MATEMATIKA. Jurnal Tatsaif. 17(1), 87-103. https://doi.org/10.20414/ita.v17i1.944

SEMOLEC. (2019). Program Bantuan Penelitian Terbuka dan Jarak Jauh 2019 Tema Pembelajaran 4.0. Retrieved from https://penelitian.seamolec.org/.

Sudihartinih, E and Wahyudin. (2019). Analysis Of Students' Self Efficacy Reviewed By Geometric Thinking Levels And Gender Using Rasch Model. Journal Of Engineering Science And Technology, 14(1), 509-519.

Sudihartinih, E. (2018a). ANALISIS KESALAHAN SISWA DALAM KONSEP TITIK DAN GARIS PADA BIDANG. Erudio (Journal of Educational Innovation), 5(1), 12-18.

Sudihartinih, E. (2018b). STUDENTS' ERRORS ON THE CIRCLE CONCEPT IN BASIC MATHEMATIC LECTURES. Erudio (Journal of Educational Innovation), 5(2), 10-16.

Sudihartinih, E. and Purniati, E. (2019). Using Geogebra to develop students understanding on circle concept. J. Phys.: Conf. Ser. 1157 042090, 1-7.

Sudihartinih, E. dan Mulyana, E. . (2014). Perkuliahan Geometri Transformasi dengan Pendekatan Kontruktivisme untuk Meningkatkan Level Berpikir Geometri van Hiele. Jurnal Pendidikan Matematika Sigma Didatika . Sigma Didaktika, 3(1), 12-16.

Sudjana, N. (1991). Penelitian Hasil Proses Belajar Mengajar. Bandung: Remaja Rosdakarya.

Suherman, E. (2003). Common Textbook Evaluasi Pembelajaran Matematika (Edisi Revisi). Bandung: Universitas Pendidikan Indonesia.

Sumintono, B.; and Widhiarso, W. (2014). Aplikasi model Rasch untuk penelitian ilmu-ilmu sosial. Cimahi, Bandung, Indonesia: Trimkom Publishing House.

Putrawangsa, S., \& Hasanah, U. (2018, August 29). INTEGRASI TEKNOLOGI DIGITAL DALAM PEMBELAJARAN DI ERA INDUSTRI 4.0. Jurnal Tatsqif, 16(1), 42-54. Retrieved from http://journal.uinmataram.ac.id/index.php/tatsqif/article/view/203

Tran T, Nguyen N G, Bui M D, Phan A H . (2014). Discovery Learning with the Help of the Geogebra Dynamic Geometry Software. International Journal of Learning, Teaching and Educational Research, 7(1) 44-57.

Wahono, R. S. (2008). Meluruskan Salah Kaprah Tentang e-learning. Retrieved from http://romisatriawahono.net/2008/01/23/meluruskan-salahkaprah-tentang-e-learning/ 